INTERNATIONAL DESIGN CONFERENCE - DESIGN 2018

https://doi.org/10.21278/idc.2018.0404

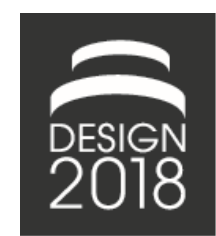

\title{
LINKING ECODESIGN CAPABILITIES TO CORPORATE PERFORMANCE: PROPOSAL OF A SIMULATION-BASED APPROACH
}

\author{
V. P. Rodrigues, D. Pigosso and T. McAloone
}

\begin{abstract}
The absence of mechanisms to evaluate the potential benefits of ecodesign prior to implementation is a major barrier to wider adoption. There is a need to understand how the development of ecodesign capabilities affect corporate performance considering its dynamic complexity. Drawing upon the Ecodesign Maturity Model, this paper systematically reviews the literature on relevant applications of dynamic modeling and develops the foundations of a simulation framework, aimed at deriving business cases for ecodesign implementation. Preliminary results and streams of future research are discussed.
\end{abstract}

Keywords: ecodesign, product development, sustainable design, system dynamics, business case

\section{Introduction}

Despite the significant growth in the number of researches and corporations reporting the benefits of ecodesign-related efforts (Plouffe et al., 2011; Haned et al., 2015; IRRC Institute, 2015), a number of challenges still hinder a broader and consistent implementation of ecodesign in manufacturing firms. There is a particular lack of proper mechanisms to evaluate the potential business benefits originated by ecodesign (McAloone, 1998; Boks, 2006; Dekoninck et al., 2016; Rodrigues et al., 2016b; Rodrigues et al., 2017a). With that, the concept of "business case" emerges as the set of arguments that support and elicits the key reasons why an organization should accept or advance a specific cause (Carroll and Shabana, 2010; Whelan and Fink, 2016).

The integration of such sustainability-related aspects into product development is considered a complex task, with high interconnectedness among variables over time (Tatikonda, 2008; Costa et al., 2014; Rodrigues et al., 2016a). Therefore, this is a problem that displays dynamic complexity, which arises from the interactions of several agents over time (Sterman, 2000). Some fundamental characteristics of systems with dynamics complexity are: constantly changing and past-dependent; tightly coupled and governed by feedback (i.e. strong interaction among variables with feedback loops); self-organizing (the system's structure drives its behavior over time); adaptive (i.e. resistance to change and adaptation to newly introduced policies) and non-linear (i.e. effects are not typically proportional to the cause) (Sterman, 2000, 2001; Repenning and Sterman, 2001). With the objective of addressing systems displaying such dynamic complexity, the System Dynamics method was proposed as an application of control theory to socio-technical complex systems, supported by computational modelling and simulation, and targeted at analyzing complex and dynamic behavior (Forrester, 1971; Sterman, 2001; Lee et al., 2012; Liao et al., 2015). It is both a modelling and simulation technique that has been widely applied to examine, understand and intervene in complex systems in a large range of disciplines and contexts. 
With a maturity-based management framework for ecodesign implementation and management (the Ecodesign Maturity Model - EcoM2) (Pigosso and Rozenfeld, 2011; Pigosso et al., 2013; Pigosso and McAloone, 2016) as the theoretical frame, this paper draws upon the particular concept of capability of ecodesign management practices with the main objective of understanding how ecodesign-related capability building might theoretically influence a range of corporate performance outcomes over time (i.e. revenue, market share, risk, costs etc.). Capability levels can be understood as a qualitative measure of how well a company applies a certain ecodesign management practice, in the context of the EcoM2 (Pigosso et al., 2013). Moreover, most business cases typically account for a posteriori analysis of the influences ecodesign-related practices, as opposed to a priori, predictive business cases, which focuses on how to collect information and measure performance. Within this context, this paper seeks to answer the following research question: how can System Dynamics support the modelling of ecodesign capabilities and their influence on corporate performance over time? This paper proposes a set of "building blocks" for an exploratory simulation-based framework with the objective of assisting the development of a business case for ecodesign implementation within manufacturing firms. The potential result of this broader research stream is intended to be used by key managers and strategic decisionmakers across the organization in their daily attributions related to both gathering information on business cases as well as presenting them to senior leadership.

\section{Research methodology}

With a view to building a simulation-based business case framework for ecodesign implementation, the research methodology employed in this paper is comprised of two phases, divided into four main steps. Initially, a systematic literature review (SLR) and a subsequent content analysis of relevant applications of dynamic modelling in the context of organizational capability and related fields were carried out. Then, the approach was formed by a generic System Dynamics modelling approach, based on the conceptualization of the problem, the formulation of variables, relationships and parameters, the evaluation of the model's behavior and the analysis of potential policies and model's use (Sterman, 2000; Luna-Reyes and Andersen, 2003; Lee et al., 2012). The phases and steps are described as follows.

\subsection{Phase 1: Review of capability modelling within a process-oriented context}

Phase 1 focused on learning what the literature of System Dynamics proposed in terms of how to approach the modelling of capability within a process-oriented context. Therefore, this phase encompassed Steps 1 and 2 of the research methodology. The first step (Step 1 - Systematic Literature Review) - was based on the procedures proposed by Biolchini et al. (2005), which builds upon the three sub-steps: (1) planning of the review process; (2) execution of the SLR and (3) analysis of the results. The sub-steps are detailed as follows:

- Review Planning: three fields were identified as relevant - namely organizational capability $(\mathrm{OC})$, product development $(\mathrm{PD})$ and project management $(\mathrm{PM})$ - due to their complementarities and proximity as research fields. The review protocol was tailored to support three independent searchers within each one of the fields, based on three groups of keywords. For the field of organizational capability, the wildcard "capabilit*" was combined with the keyword "system dynamics". For product development field, six synonyms for product development ("product development", "engineering design", "concurrent engineering", "eco-design", "ecodesign" and "design for environment") were combined with the "system dynamics" keyword. Finally, for the field of project management, the "project management" keyword was combined directly with "system dynamics". The selected database for performing the searches was Web of Science due to its relevance to the fields of study and rigor in study selection (Gavel and Iselid, 2008; Adriaanse and Rensleigh, 2013). Only journal papers in English were searched. Two inclusion criteria were defined for the papers to meet: (1) propose, report or review at least one SD formulation and (2) focus on an organizational context or application. Based on the two proposed criteria, the papers were then examined by reading the: (a) title, (b) abstract and keywords, (c) schematic figures and representations, introduction and conclusion and finally (d) reading the full paper; 
- Review Execution: once the papers were selected, the information on the SD application was extracted and catalogued in a paper repository, classified according to the field of application (OC, PD or PM). Supplementary information and other comments on relevant aspects of the paper were also recorded in order to support content analysis.

- Analysis of Results: the repository of selected papers was finally consolidated and systematized in a reference manager software for easy access and analysis, which was materialized in Step 2;

Subsequently, the second step (Step 2 - Content Analysis) was performed in order to identify the key elements and the emerging patterns in the papers selected in Step 1 (Bashor, 2003; Starks and Trinidad, 2007). These elements and patterns were composed of SD formulations, conceptualizations or any other modelling strategies that were relevant to the dynamic modelling effort in this research. In particular, the content analysis aimed at identifying SD structures that could be potentially useful for depicting and modelling the development of ecodesign capabilities and their links to corporate performance, within the context of the EcoM2.

\subsection{Phase 2: SD model conceptualization}

Subsequently, Phase 2 concentrated on conceptualizing a SD model based on formulations derived from the literature, and reorganizing the set of ecodesign management practices in order to a better level of aggregation for modelling.

The third step (Step 3 - System Dynamics Modelling) had a stock and flow diagram developed as the basis of the working simulation model, with the objective of describing the accumulations (stocks) and rates of increase/decrease (flow) of key variables in the system (Sterman, 2000; Dangelico et al., 2010; Liao et al., 2015). The SD model was built using the software package Stella Architect version 1.4.1, developed by isee systems.

Finally, the fourth step (Step 4 - Clustering of Management Practices) entailed an inductive thematic analysis (Braun and Clarke, 2006; Eisenhardt and Graebner, 2007), which was employed towards analyzing themes/patterns within the body of 51 ecodesign management practices of the EcoM2. In particular, this step was required in order to reorganize the full set of ecodesign management practices to form a higher level of aggregation for the analysis of the management practices. The themes/patterns emerged entirely from the data at hand to form clusters of practices, and no attempts were made towards fitting the practices into a preconceived theoretical framework. Thematic analysis was particularly helpful for clustering the practices due to the commonalities and recurring themes displayed in the ecodesign management practices. Triangulation methods were used with the objective of improving research validity and trustworthiness. In particular, investigator triangulation (Curtin and Fossey, 2007; Kitto et al., 2008) was applied, procedure in which multiple investigators perform the analysis independently, in an effort to significantly reduce bias (Curtin and Fossey, 2007).

\section{Results and discussion}

\subsection{Results and discussion from Phase 1}

The performance of the systematic literature review resulted in three independent searches. In total, 492 papers were evaluated according to the inclusion criteria (Table 1).

Table 1. Number of papers analyzed in the systematic literature review per field

\begin{tabular}{|c|c|c|c|c|}
\hline $\begin{array}{c}\text { Evaluation } \\
\text { Steps }\end{array}$ & $\begin{array}{c}\text { Organizational } \\
\text { Capability }\end{array}$ & $\begin{array}{c}\text { Product Development } \\
\text { Processes }\end{array}$ & $\begin{array}{c}\text { Project } \\
\text { Management }\end{array}$ & $\begin{array}{c}\text { Total per } \\
\text { step }\end{array}$ \\
\hline Total number of papers & 346 & 66 & 80 & 492 \\
\hline Abstract and keywords & 231 & 45 & 58 & 334 \\
\hline $\begin{array}{c}\text { Schematic figures, } \\
\text { introduction and } \\
\text { conclusion }\end{array}$ & 188 & 37 & 30 & 255 \\
\hline Selected papers & $\mathbf{2 5 ( 7 \% )}$ & $\mathbf{2 3 ( 3 5 \% )}$ & $\mathbf{2 1 ( 2 6 \% )}$ & $\mathbf{6 9}(\mathbf{1 4 \% )}$ \\
\hline
\end{tabular}

Even though the search in the fields of organizational capability was expected to provide the largest number of selected papers - due to its relevance to the core topic of our modelling efforts - it turned out 
to be the lowest yield (7\%). One of the main reasons for such a low yield has to do with the fact that the majority of dismissed papers were related to qualitative discussions around the topic of organizational capability, supported by a "systems thinking" lens, therefore neither providing a suggestion of SD structure nor a modelling strategy. Moreover, as capability itself has become a very broad a widely used term, several papers were dismissed because they were treating capability with a completely different definition or from an unusual point of view. However, the selected papers from the searches in this field proved to be among the most relevant ones in terms of providing substantial contributions towards building a SD model for capability development, because they were explicitly modelling organizational capability and defining the model parameters and boundaries around this core concept.

As for the searches in the fields of product development processes, which resulted in the highest yield $(35 \%)$, the majority of the papers developed models or analysis at a very granular level (e.g. design tasks, time allocation, team structure etc.). Several studies in this field focus on product launches and market conditions of newly launched products, with many papers emphasizing the marketing lifecycle of products and how to plan accordingly (e.g. based on the classic Bass diffusion model). Furthermore, most of the SD applications in product development were not explicitly modelling the concept of capability. Bearing a lot of overlaps and similarities with the literature from the product development field, the search in the field of project management has also produced a relatively high yield $(26 \%)$. Similarly, the proposed models in this literature were more granular (e.g. tasks, backlog, costs, resource allocation etc.) and were not treating capability explicitly. The literature on project management was particularly helpful to understand how to structure project-specific models, whose main objective is to solve particular management challenges relative to the project's scope, quality, time or cost. In a broader sense, this particular field has not informed our modelling efforts towards building a generic approach for capability development in ecodesign. Therefore, it is possible to assert that relevant literature on SD applications to the modelling of capability in organizations is scarce and highly concentrated on few researchers and research groups. Table 2 provides a summary and overview of some papers (pulled out from the group of 69 selected papers) that were utilized as theoretical basis for the modelling efforts described later in this paper..

Table 2. Summary of the main contributions of selected papers from the SLR

\begin{tabular}{|c|c|c|c|c|}
\hline \multirow[t]{3}{*}{ Field/Search } & \multirow[t]{3}{*}{ Reference } & \multicolumn{3}{|c|}{ Main contribution to the modelling effort } \\
\hline & & \multicolumn{2}{|c|}{ Type of contribution } & \multirow[t]{2}{*}{ Comments } \\
\hline & & Specific & Generic & \\
\hline \multirow[t]{7}{*}{$\begin{array}{l}\text { Organizational } \\
\text { Capability }\end{array}$} & $\begin{array}{l}\text { (Rahmandad et al., } \\
\text { 2016) }\end{array}$ & $\mathrm{X}$ & & $\begin{array}{c}\text { Stock and flow formulation of } \\
\text { organizational capability }\end{array}$ \\
\hline & $\begin{array}{l}\text { (Rahmandad and } \\
\text { Repenning, 2016) }\end{array}$ & $\mathrm{X}$ & & $\begin{array}{l}\text { Theoretical considerations on } \\
\text { capability erosion }\end{array}$ \\
\hline & (Rahmandad, 2015) & $\mathrm{X}$ & $\mathrm{X}$ & $\begin{array}{c}\text { Discussion on capability definitions } \\
\text { (general) and typology, and stock and } \\
\text { flow formulation (specific) }\end{array}$ \\
\hline & (Morrison, 2012) & & $\mathrm{X}$ & $\begin{array}{l}\text { Further development on the concept } \\
\text { of capability traps }\end{array}$ \\
\hline & (Rahmandad, 2012) & $\mathrm{X}$ & & $\begin{array}{c}\text { Stock and flow formulation of } \\
\text { organizational capability }\end{array}$ \\
\hline & $\begin{array}{l}\text { (Repenning and } \\
\text { Sterman, 2002) }\end{array}$ & & $\mathrm{X}$ & \multirow{2}{*}{$\begin{array}{c}\text { Conceptualization and formulation of } \\
\text { the capability traps }\end{array}$} \\
\hline & $\begin{array}{l}\text { (Repenning and } \\
\text { Sterman, 2001) }\end{array}$ & & $\mathrm{X}$ & \\
\hline \multirow{3}{*}{$\begin{array}{l}\text { Product } \\
\text { Development } \\
\text { Processes }\end{array}$} & (Repenning, 2004) & & $\mathrm{X}$ & $\begin{array}{l}\text { Application of System Dynamics to a } \\
\text { socio-technical context }\end{array}$ \\
\hline & (Repenning, 2001) & & $\mathrm{X}$ & $\begin{array}{c}\text { Concept of "firefighting" in product } \\
\text { development }\end{array}$ \\
\hline & $\begin{array}{c}\text { (Ford and Sterman, } \\
1998)\end{array}$ & & $\mathrm{X}$ & $\begin{array}{l}\text { Overview of dynamic modelling } \\
\text { applied to PD processes }\end{array}$ \\
\hline
\end{tabular}


Even though all 69 selected papers were useful towards framing the business case modelling approach, the ten papers represented on Table 2 were selected to be displayed based on their higher relevance as guides for our modelling efforts

\subsection{Results and discussion from Phase 2}

\subsubsection{Ecodesign capability as a stock-and-flow structure}

Regarding the capability measurement within the EcoM2, the model defines a 5-point scale to measure how well a practice is applied, based on the CMMI (Chrissis et al., 2011; Pigosso et al., 2013). These 5 capability levels are: level 1 (incomplete) means that a practice is not considered at all or is applied in an incomplete way; level 2 ( $a d$ hoc) defines a practice as only being applied to accomplish very specific tasks or correct certain issues; level 3 (formalized) is reached when the practice is fully documented and accompanied by an account of its resources, infrastructure and responsibilities; level 4 (controlled) brings the ecodesign management practice to a controlled/monitored space, meaning that performance is measured and monitored; level 5 (improved) means that the ecodesign management practice has its performance continuously and systematically improved over time.

In the proposed framework, management practices will be treated and modelled as having an independent capability. In the field of strategy, the resource-based view of the firm builds upon the concept that organizations are "bundles" of capabilities and resources (Rahmandad, 2015). The resources can be composed of tangible assets (e.g. human resources, machinery, capital etc.) or intangible assets (e.g. intellectual property, reputation etc.), while capabilities can be understood as organizational routines through which organizations perform several tasks in order to produce products and services (Winter, 2000; Rahmandad, 2015). Capabilities, in turn, can be distinguished between operational and dynamic capabilities (Winter, 2003). While operational capabilities allow the firm to perform short-term activities (e.g. production, sales, customer care etc.) and survive, the dynamic capabilities are connected to higher-order routines that firms use to extend their competences and change other capabilities (Teece, 2007; Rahmandad, 2015; Pisano, 2017).

Aligned with the formulations in the literature (Rahmandad, 2012; Rahmandad et al., 2016), ecodesign capability is then conceptualized as a stock variable, which changes according to two main mechanisms (flows): capability development and capability erosion. Since capabilities cannot be directly acquired (Dierickx and Cool, 1989), managers can only influence its rate of change over time, as opposed to influencing its stock level directly. Figure 1 displays the generic structure of a stock and flow diagram to represent the capability of ecodesign management practices.

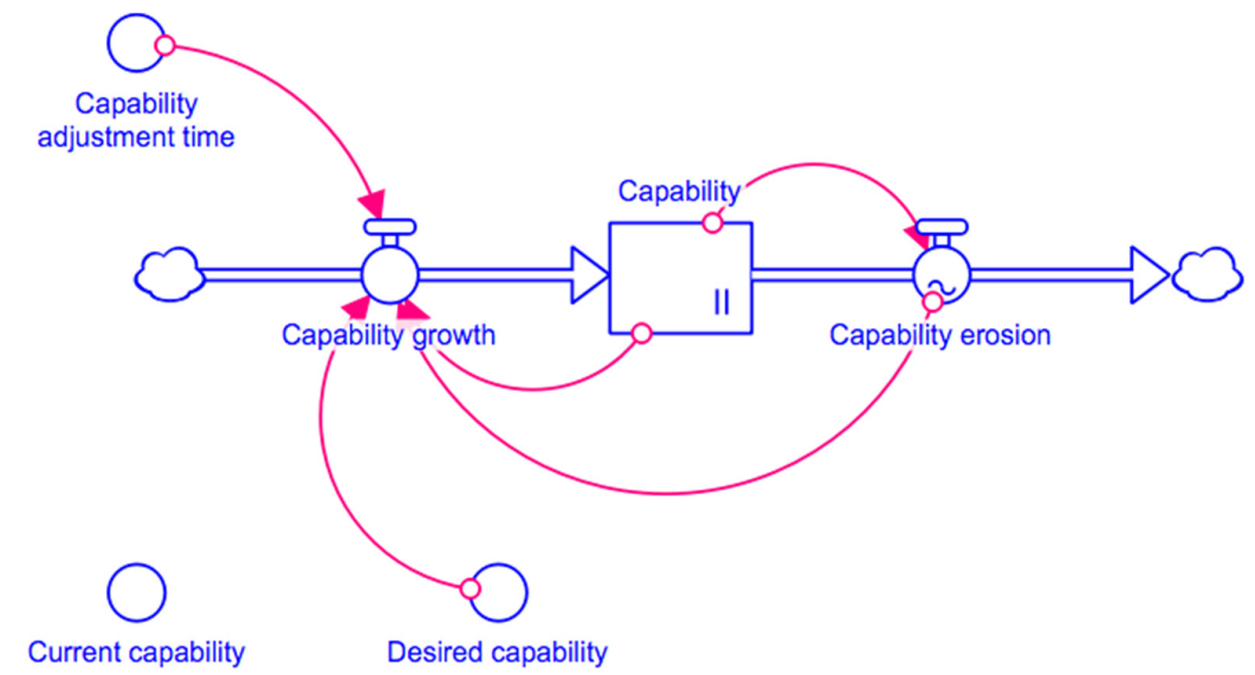

Figure 1. Generic stock and flow structure for practice's capability

The capability stocks are initialized with the current capability $(C C)$, which is the result of diagnosis steps in the EcoM2. The goal of managers is to then reach the desired capability (DC), which comes 
from the visioning step of the EcoM2. The capability investment rate is then based on a "stock management structure" formulation (Sterman, 2000), which has an inflow (capability investment) adjusting to a goal (desired capability) and also taking into consideration the expected outflow (capability erosion - $C E$ ). Therefore, the capability, $C$, is constantly changing as a function of the processes of capability investment, $C I$, and capability erosion, $C E$, and is given by:

$$
\begin{aligned}
& \frac{d C}{d t}=C I-C E \\
& C I=\operatorname{SMTH}(\mathrm{CE}, \text { Averaging Time })+\frac{(\mathrm{DC}-\mathrm{C})}{C A T}
\end{aligned}
$$

Equation (1) describes the variation of the capability stock over time. Equation (2) gives the formulation for the inflow. Since the instantaneous rate cannot be measured, the expected outflow (CE) is usually formulated by averaging the past outflows (exponential smoothing - SMTH) (Sterman, 2000), together with the gap between capability level and the desired capability being adjusted in terms of the capability adjustment time $(C A T)$. This exogenous adjustment time (parameter) can be understood as the average time required to close the gap (Sterman, 2000). In other words, it can be seen, from an implementation point of view, as the time for improvements in ecodesign capability to be perceived and materialized by the company - representing the time needed to adjust for the desired capability level for a particular practice. This parameter can be set by the manager in order to reflect the particular context of a company.

Additionally, the erosion mechanisms are grounded in the concept of "organizational forgetting", with turnover and insufficient organizational memory as the main elements driving the erosion of capability (Rahmandad and Repenning, 2016). The capability erosion flow is based on a graphic function (also known as table function), in which the erosion decreases when the capability increases, as a result of the increased level of systematization, documentation and routineness reached at higher capability levels (Pigosso et al., 2013), therefore $C E=f(C)$. The highest erosion rate is reached between capability levels 1 and 2, and then decreases as the capability level increases from level 2 onwards. This function shape is preferred over a hump-shaped curve (i.e. with capability erosion increasing for capability levels from 1 to 2 and then decreasing afterwards), because a hump-shaped curve is ambiguous in terms of the influence of capability on capability erosion, as it indicates the presence of multiple causal pathways between the capability level and rate of capability erosion (Sterman, 2000).

\subsubsection{Linking capability to corporate performance}

Corporate performance is formulated as a Cobb-Douglas function of the capability, in line with the literature on organizational capability (Sterman, 2000; Repenning and Henderson, 2010; Rahmandad, 2012; Rahmandad et al., 2016). This is a very well-known product function formulation in the fields of economics and econometrics (see, for instance, Cobb and Douglas, 1928). In its most standard form, the Cobb-Douglas function represents an output $Y$ (e.g. production) as a function of two inputs $L$ and $K$ (e.g. labor and capital):

$$
Y=A L^{\alpha} K^{\beta}
$$

In Equation (3), $\alpha$ and $\beta$ are the output elasticities relative to each one of the inputs, $L$ and $K$, respectively, and $A$ is a productivity factor. This means that an $1 \%$ increase in $L$ will lead to an approximately $\alpha \%$ increase in the output, if everything else is held equal. Similarly, an $1 \%$ increase in $K$ will lead to an approximately $\beta \%$ increase, ceteris paribus. If $\alpha+\beta=1$, then the function displays constant returns to scale. If $\alpha+\beta<1$, returns to scale are decreasing and, if $\alpha+\beta>1$, returns to scale are increasing. More generally, the Cobb-Douglas function can be written as follows for N inputs:

$$
Y=f(x)=A \prod_{i=1}^{N} x_{i}^{\lambda_{i}}, x=\left(x_{1}, \ldots, x_{N}\right)
$$

Instantiating the Cobb-Douglas function for an example in our formulation for the development of ecodesign capabilities, with two capabilities, say $C_{1}$ and $C_{2}$, contributing to the company's performance (e.g. revenue, $R$ ), it would take the form: 


$$
R=A C_{1}^{\alpha} C_{2}^{\beta}, \text { with } \alpha+\beta>1
$$

Since ecodesign capabilities are expected to exhibit increasing returns to scale - i.e. the higher the capability level, the higher its contribution to performance (Pigosso et al., 2013) - parameters $\alpha$ and $\beta$ can be defined such as $\alpha+\beta>1$. For instance, setting $\alpha=0.8$ and $\beta=0.6$, hypothetically, we assume that for each $1 \%$ increment in the capability $1\left(C_{1}\right)$, revenue will be incremented by $0.8 \%$, whereas a $1 \%$ increase in the capability $2\left(C_{2}\right)$, revenue will increase by $0.6 \%$. Figure 2 displays the surface generated (Figure 2a) by the Cobb-Douglas function (5), along with its contour plot (Figure 2b) showing the isoquant curves.

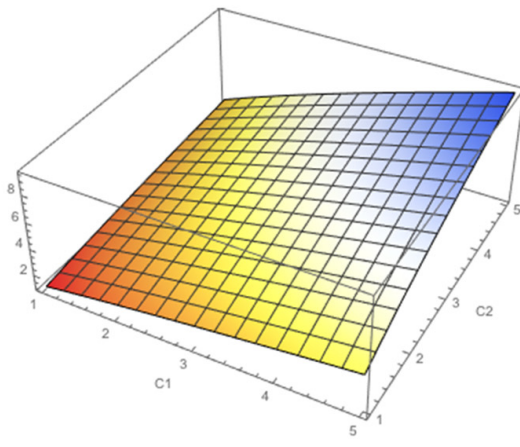

(a)

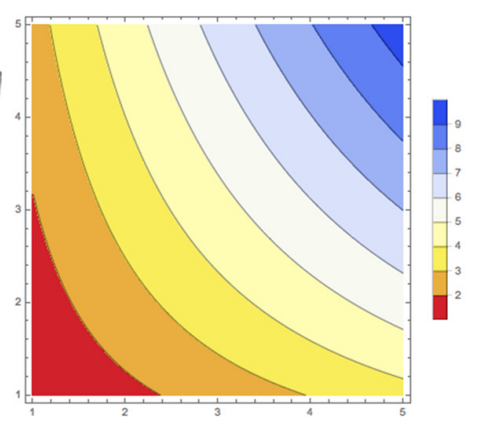

(b)

Figure 2. (a) curve generated by the hypothetical Cobb-Douglas function for corporate performance with two capabilities ( $\mathrm{C} 1$ and $\mathrm{C2}$ ); (b) isoquant curves

An SD representation of such model is presented on Figure 3. The model represents a generic set of two ecodesign practices linked - through the Cobb-Douglas function - to a corporate performance indicator, namely revenue. Each one of the capabilities $\left(C_{1}\right.$ and $\left.C_{2}\right)$ can have its own parameters, such as the capability adjustment time and the capability erosion curve. For simplicity and considering the exploratory aspects of this paper, these parameters are considered to be the same for the two different of capabilities. Moreover, each one of the capabilities has its own current level (result of the EcoM2 diagnosis) - which initializes the stock of capability - and the desired level (result of the visioning exercise of the EcoM2). Clearly, this model can grow further with: (i) links to new performance outcomes (e.g. risk, brand equity, profits etc.) and (ii) synergistic relationships between practices (e.g. the capability $C_{1}$ influences the growth of capability $C_{2}$ ).

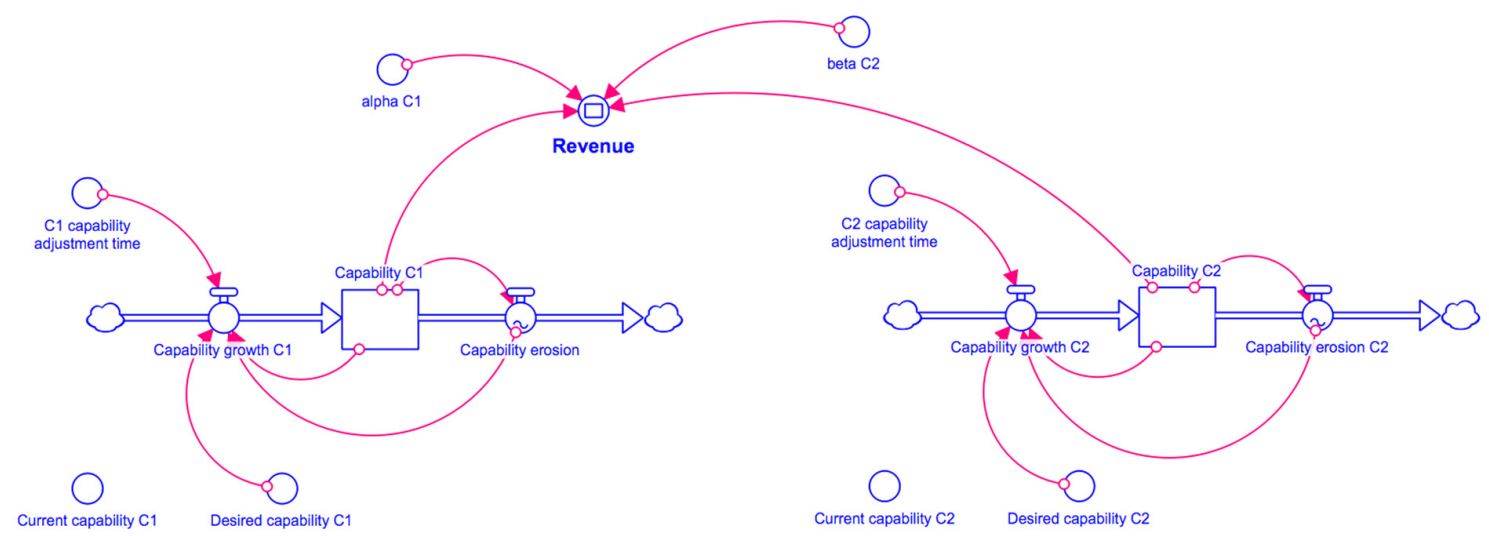

Figure 3. Simplified SD model for a business case with two generic practices and one performance outcome (revenue)

One of the main challenges based on this modelling approach is how to represent the full set of ecodesign management practices (51 practices). Since the main objective of the business case is to bridge the gap 
between ecodesign roadmaps and their actual implementation, corporate decision-makers might not necessarily make judgments and assessments at the granular level of the individual practice. This would amount to a total of, at least, 51 variables to be factored and taken into account when designing a business case. This might be intractable in practice. Therefore, an adjustment to the aggregation level of the model is required. With that, practices were clustered according to their thematic affinity through content analysis procedures (thematic analysis). In particular, the clusters of practices are particularly important to support corporate decision-makers in quickly identifying the practices by their theme. Besides allowing decision-makers to better connect the ecodesign practices to their own company's structure and processes, the clustered representation of practices also supports a more straightforward manipulation and development of the business cases.

\subsubsection{Clustering of ecodesign management practices}

As described in the section of research methodology, a thematic analysis was conducted in order to derive clusters of practice.

The ecodesign management practices (EMP) are related to the integration of environmental issues into the strategic and tactical levels of the product development process. The total number of consolidated EMPs in the EcoM2 is fifty-one. The management practices are process-related, generic and applicable to any company, regardless of a product's specific feature (Pigosso et al., 2013). Examples of ecodesign management practices include (Pigosso et al., 2013; Pigosso and McAloone, 2015, 2016): "monitor the product environmental performance during use and end-of-life phases of the life cycle" and "elaborate and communicate recommendations to consumers on how to improve the environmental performance of the product during the use and end-of-life phases". Such practices are process-oriented, which means they are not targeting particular characteristics of products, such as material, shape or any other product-specific technical feature. In this sense, the ecodesign management practices provides a view that is aimed at integrating the company's entire portfolio of products, as opposed to focusing on specific products.

The researchers analyzed the ecodesign management practices separately and had three subsequent meetings to discuss emerging themes until agreement was ultimately reached. After the performance of the inductive thematic analysis, 51 ecodesign management practices were organized in 11 clusters of practice. The management practices inside a given cluster are sufficiently homogeneous, while being heterogeneous across all the clusters. Table 3 exhibits the clusters of practices derived from the thematic analysis, together with examples of practices in the cluster.

Table 3. Clusters of ecodesign management practices, with examples

\begin{tabular}{|c|c|c|c|}
\hline $\begin{array}{c}\text { Cluster } \\
\#\end{array}$ & Thematic cluster & $\begin{array}{l}\text { Number of } \\
\text { practices in } \\
\text { the cluster }\end{array}$ & Examples of practice in the cluster \\
\hline 1 & $\begin{array}{l}\text { Environmentally- } \\
\text { enhanced technological } \\
\text { strategy }\end{array}$ & 5 practices & $\begin{array}{c}\text { Identify and/or develop new technologies that can } \\
\text { contribute to improve the product's environmental } \\
\text { performance }\end{array}$ \\
\hline 2 & $\begin{array}{l}\text { Development of support } \\
\text { processes, training and } \\
\text { knowledge for ecodesign }\end{array}$ & 4 practices & $\begin{array}{c}\text { Get knowledge on how to develop products with a } \\
\text { better environmental performance }\end{array}$ \\
\hline 3 & $\begin{array}{l}\text { Incentives and awareness } \\
\text { for ecodesign }\end{array}$ & 2 practices & $\begin{array}{c}\text { Develop a "green" incentive scheme for the } \\
\text { development of products }\end{array}$ \\
\hline 4 & $\begin{array}{l}\text { Marketing and } \\
\text { communication for } \\
\text { ecodesign }\end{array}$ & 2 practices & $\begin{array}{l}\text { Communicate the environmental performance and } \\
\text { benefits as part of the total value proposition of the } \\
\text { product, exploring the green marketing opportunities }\end{array}$ \\
\hline 5 & $\begin{array}{l}\text { End-of-life strategies, } \\
\text { packaging and operations }\end{array}$ & 5 practices & $\begin{array}{c}\text { Select and/or develop new manufacturing and } \\
\text { processes with improved environmental performance }\end{array}$ \\
\hline 6 & $\begin{array}{l}\text { Strategic management of } \\
\text { ecodesign } \\
\text { implementation }\end{array}$ & 9 practices & $\begin{array}{c}\text { Develop business, product and market strategies } \\
\text { considering the environmental trends }\end{array}$ \\
\hline
\end{tabular}




\begin{tabular}{|c|c|c|c|}
\hline 7 & $\begin{array}{l}\text { Portfolio management } \\
\text { and environmental trends }\end{array}$ & 4 practices & $\begin{array}{c}\text { Evaluate the environmental feasibility of new product } \\
\text { development projects }\end{array}$ \\
\hline 8 & $\begin{array}{l}\text { Product development } \\
\text { management }\end{array}$ & 11 practices & Implement Life Cycle Thinking \\
\hline 9 & Value chain management & 3 practices & $\begin{array}{l}\text { Establish cooperation programs and joint goals with } \\
\text { suppliers and partners }\end{array}$ \\
\hline 10 & Regulatory compliance & 2 practices & $\begin{array}{l}\text { Formulate mandatory rules and/or product } \\
\text { requirements }\end{array}$ \\
\hline 11 & $\begin{array}{l}\text { Program management } \\
\text { and ecodesign } \\
\text { benchmarking }\end{array}$ & 4 practices & $\begin{array}{c}\text { Benchmark the environmental performance of } \\
\text { competitor products }\end{array}$ \\
\hline
\end{tabular}

\subsubsection{Application of the business case in an ecodesign management context}

The expansion of the SD model structure presented in this paper (see Figure 3) to cover other clusters of practice can, therefore, lead to the development of structured and more rigorously grounded business cases for ecodesign implementation. With a comprehensive simulation model covering all (clusters of) practices in the EcoM2, managers will be able to experiment on the business case simulator to test different scenarios and ecodesign implementation paths. This means that decision-makers will be able to evaluate how different speeds and strategies of implementation (e.g. which clusters to focus and how fast to implement them) could potentially lead to changes in their company's most strategic performance outcomes, such as revenue, risk, and others.

In terms of actual implementation of ecodesign, the EcoM2 also prescribes an application method for manufacturing companies to follow. The first phase has 3 application steps: 1) the diagnosis of the current maturity profile, whose main output is the current capability levels of the management practices; 2) the definition of a vision for improved maturity, according to the company's strategy and drivers, and whose main output is the desired capability levels for the management practices and 3) the deployment of actionable roadmaps of improvement projects, based on the gap between current capability levels (Step 1) and desired, future capability levels (Step 2). The second phase entails project implementation, outlined in the roadmaps, together with efforts in change management and performance measurement. The business case plays a very important role in connecting the deployment of structured roadmaps with actual, consistent implementation. The business case framework therefore makes use of the current and desired capability levels - derived from Steps 1 and 2 - to simulate the expected behavior of selected corporate performance outcomes, under specific circumstances and assumptions.

\section{Final remarks}

This paper aimed at presenting the foundations of a simulation-based framework for the development of business cases for ecodesign implementation. The main objective was to develop approximations towards answering how ecodesign capabilities affect corporate performance over time. Initially, a systematic literature review was conducted with a view to surveying the literature on applicable uses of the System Dynamics methodology within the context of organizational capability development. Afterwards, the literature was analyzed, and the structures of a business case framework were presented and discussed. The results highlighted that the System Dynamics methodology is an adequate tool for modelling organization capability in the product development space. Despite the scarcity and concentration of the studies applying System Dynamics to organizational capability, an initial foundation can be built in order to instantiate specialized knowledge in ecodesign implementation. It is important to emphasize that this research is part of a broader effort towards building a solid understanding of how ecodesign performance can be captured, measured and this translated into useful business cases that support decision-making in product development.

Due to its exploratory nature, this research has limitations: (i) the choice of keyword and literature databases to be searched might limit the comprehensiveness of the literature review; (ii) the lack of empirical evidence/validation for both the parameters and he analytic formulations can constrain the applicability of the models; (iii) expanding the model to cover all clusters of practice might reveal operational difficulties that have not been anticipated yet by this exploratory, theoretical study. 
Therefore, future research streams should ideally focus on: (a) expanding the coverage of the systematic literature review; (b) designing and performing empirical studies for the development of more robust parameters and analytic expressions and (c) developing a structured approach for the expansion of the model to cover all clusters of ecodesign practices (relative to both the relationships between clusters as well as the relationships between clusters and other corporate performance outcomes).

Regarding the next steps in the actual development of the business cases, a set of activities can be also put forth: (i) the definition of an overall framework upon which the performance outcomes can be structured, such as the Balanced Scorecard, or similar performance measurement frameworks; (ii) the systematization of a DSM-like matrix establishing the relationship among different clusters of ecodesign practices; (iii) the systematization of a DSM-like matrix connecting the various clusters with the corporate performance outcomes they will potentially influence, with an qualitative indication of the strength of such influence; (iv) the collection of theoretical (i.e. scientific literature) and empirical (e.g. interview with experts) evidence to support the matrices on the relationships among clusters and between clusters and outcomes and, finally (v) the validation of the simulation-based business case framework with ecodesign managers in corporate decision-making settings.

\section{References}

Adriaanse, L.S. and Rensleigh, C. (2013), "Web of Science, Scopus and Google Scholar: A content comprehensiveness comparison", The Electronic Library, Vol. 31 No. 6, pp. 727-744. https://doi.org/10.1108/EL-12-2011-0174

Bashor, H.W. (2003), "Content analysis of short, structured texts: The need for multifaceted strategies", In: Lagerwerf, L., Spooren, W. and Degand, L. (Eds.), Determination of Information and Tenor in Texts: Multidisciplinary Approach to Discourse, Stichting Neerlandistiek VU, Amsterdam, p. 165-178.

Biolchini, J., Mian, P.G., Candida, A. and Natali, C. (2005), Systematic Review in Software Engineering. [online] Systems Engineering and Computer Science Department, COPPE / UFRJ, Rio de Janeiro. Available at: https://pdfs.semanticscholar.org/8004/558792c00764d173dc63c03d3a391acfe6b7.pdf

Boks, C. (2006), “The soft side of ecodesign”, Journal of Cleaner Production, Vol. 14 No. 15-16, pp. 1346-1356. https://doi.org/10.1016/j.jclepro.2005.11.015

Braun, V. and Clarke, V. (2006), "Using thematic analysis in psychology Using thematic analysis in psychology", Qualitative Research in Psychology, Vol. 3 No. 2, pp. 77-101. https://doi.org/10.1191/1478088706qp063oa

Carroll, A.B. and Shabana, K.M. (2010), "The Business Case for Corporate Social Responsibility: A Review of Concepts, Research and Practice”, International Journal of Management Reviews, Vol. 12 No. 1, pp. 85-105. https://doi.org/10.1111/j.1468-2370.2009.00275.x

Chrissis, M.B., Konrad, M. and Shrum, S. (2011), CMMI (Capability Maturity Model Integration): Guidelines for Process Integration and Product Improvement, Addison-Wesley Professional, Boston.

Cobb, C.W. and Douglas, P.H. (1928), "A Theory of Production”, The American Economic Review, Vol. 18 No. 1, pp. 139-165.

Costa, J.M.H., Oehmen, J., Rebentisch, E. and Nightingale, D. (2014), “Toward a better comprehension of Lean metrics for research and product development management”, R\&D Management, Vol. 44 No. 4, pp. $370-383$. https://doi.org/10.1111/radm.12074

Curtin, M. and Fossey, E. (2007), "Appraising the trustworthiness of qualitative studies: Guidelines for occupational therapists", Australian Occupational Therapy Journal, Vol. 54 No. 2, pp. 88-94. https://doi.org/10.1111/j.1440-1630.2007.00661.x

Dangelico, R.M., Garavelli, A.C. and Petruzzelli, A.M. (2010), “A system dynamics model to analyze technology districts' evolution in a knowledge-based perspective”, Technovation, Vol. 30 No. 2, pp. 142-153. https://doi.org/10.1016/j.technovation.2009.09.006

Dekoninck, E.A., Domingo, L., Hare, J.A.O., Pigosso, D.C.A., Reyes, T. and Troussier, N. (2016), "Defining the challenges for ecodesign implementation in companies: Development and consolidation of a framework", Journal of Cleaner Production, Vol. 135, pp. 410-425. https://doi.org/10.1016/j.jclepro.2016.06.045

Dierickx, I. and Cool, K. (1989), "Asset Stock Accumulation and Sustainability of Competitive Advantage", Management Science, Vol. 35 No. 12, pp. 1504-1511. https://doi.org/10.1287/mnsc.35.12.1504

Eisenhardt, K.M. and Graebner, M.E. (2007), "Theory building from cases: opportunities and challenges", Academy of Management Journal, Vol. 50 No. 1, pp. 25-32. https://doi.org/10.5465/AMJ.2007.24160888

Ford, D.N. and Sterman, J.D. (1998), "Dynamic modeling of product development processes", System Dynamics Review, Vol. 14 No. 1, pp. 31-68. https://doi.org/10.1002/(SICI)1099-1727(199821)14:1<31::AIDSDR141>3.0.CO;2-5 
Forrester, J.W. (1971), “Counterintuitive behavior of social systems”, Technological Forecasting and Social Change, Vol. 3, pp. 1-22. https://doi.org/10.1016/S0040-1625(71)80001-X

Gavel, Y. and Iselid, L. (2008), "Web of Science and Scopus: a journal title overlap study", Online Information Review, Vol. 32 No. 1, pp. 8-21. https://doi.org/10.1108/14684520810865958

Haned, N., Lanoie, P., Plouffe, S. and Vernier, M.-F. (2015), Profitability of Ecodesign: an Economic Analysis. [online] HEC Montreal. Available at: http://www.hec.ca/iea/cahiers/2015/dea_1501_lanoiep.pdf

IRRC Institute (2015), Driving Revenue Growth Through Sustainable Products and Services, New York.

Kitto, S.C., Chesters, J. and Grbich, C. (2008), "Quality in qualitative research", Medical Journal of Australia, Vol. 188 No. 4, pp. 243-246.

Lee, S., Geum, Y., Lee, H. and Park, Y. (2012), "Dynamic and multidimensional measurement of product-service system (PSS) sustainability: A triple bottom line (TBL)-based system dynamics approach”, Journal of Cleaner Production, Vol. 32, pp. 173-182. https://doi.org/10.1016/j.jclepro.2012.03.032

Liao, Y.-W., Wang, Y.-M., Wang, Y.-S. and Tu, Y.-M. (2015), "Understanding the dynamics between organizational IT investment strategy and market performance: A system dynamics approach", Computers in Industry, Vol. 71, pp. 46-57. https://doi.org/10.1016/j.compind.2015.02.006

Luna-Reyes, L.F. and Andersen, D.L. (2003), "Collecting and analyzing qualitative data for system dynamics: methods and models", System Dynamics Review, Vol. 19 No. 4, pp. 271-296. https://doi.org/10.1002/sdr.280

McAloone, T. (1998), Industry Experiences of Environmentally Conscious Design Integration: An Exploratory Study, $\mathrm{PhD}$ thesis, Cranfield University.

Morrison, J.B. (2012), "Process improvement dynamics under constrained resources: managing the work harder versus work smarter balance", System Dynamics Review, Vol. 28 No. 4, pp. 329-350. https://doi.org/10.1002/sdr.1485

Pigosso, D.C. and McAloone, T.C. (2015), "Best practices for the integration of social sustainability into product development and related processes", Sustainable Innovation 2015, Epsom, UK, November 9-10, 2015, The Centre for Sustainable Design, Epsom, pp. 1-4.

Pigosso, D.C.A. and McAloone, T.C. (2016), "Maturity-based approach for the development of environmentally sustainable product/service-systems", CIRP Journal of Manufacturing Science and Technology, Vol. 15, pp. 33-41. https://doi.org/10.1016/j.cirpj.2016.04.003

Pigosso, D.C.A. and Rozenfeld, H. (2011), "Proposal of an Ecodesign Maturity Model: Supporting companies to improve environmental sustainability", Glocalized Solutions for Sustainability in Manufacturing: Proceedings of the $18^{\text {th }}$ CIRP International Conference on Life Cycle Engineering, Braunschwieg, Germany, May 2-4, 2011, Springer, Berlin, pp. 136-141. https://doi.org/10.1007/978-3-642-19692-8_24

Pigosso, D.C.A., Rozenfeld, H. and McAloone, T.C. (2013), "Ecodesign maturity model: A management framework to support ecodesign implementation into manufacturing companies", Journal of Cleaner Production, Vol. 59, pp. 160-173. https://doi.org/10.1016/j.jclepro.2013.06.040

Pisano, G.P. (2017), "Toward a prescriptive theory of dynamic capabilities: connecting strategic choice, learning, and competition", Industrial and Corporate Change, Vol. 26 No. 5, pp. 747-762. https://doi.org/10.1093/icc/dtx026

Plouffe, S., Lanoie, P., Berneman, C. and Vernier, M.F. (2011), "Economic benefits tied to ecodesign", Journal of Cleaner Production, Vol. 19 No. 6-7, pp. 573-579. https://doi.org/10.1016/j.jclepro.2010.12.003

Rahmandad, H. (2012), "Impact of Growth Opportunities and Competition on Firm-Level Capability Development Trade-offs", Organization Science, Vol. 23 No. 1, pp. 138-154. https://doi.org/10.1287/orsc. 1100.0628

Rahmandad, H. (2015), "Connecting strategy and system dynamics: an example and lessons learned", System Dynamics Review, Vol. 31 No. 3, pp. 149-172. https://doi.org/10.1002/sdr.1541

Rahmandad, H. and Repenning, N.P. (2016), "Capability Erosion Dynamics", Strategic Management Journal, Vol. 37, pp. 649-672. https://doi.org/10.1002/smj.2354

Rahmandad, H., Henderson, R. and Repenning, N.P. (2016), "Making the Numbers? 'Short termism' and the puzzle of only occasional disaster", Management Science, Vol. 64 No. 3, pp. 1-21. https://doi.org/10.1287/mnsc.2016.2670

Repenning, N.P. (2001), "Understanding fire fighting in new product development", Journal of Product Innovation Management, Vol. 18 No. 5, pp. 285-300. https://doi.org/10.1111/1540-5885.1850285

Repenning, N.P. (2004), "Selling system dynamics to (other) social scientists", System Dynamics Review, Vol. 19 No. 4, pp. 303-327. https://doi.org/10.1002/sdr.278

Repenning, N.P. and Henderson, R.M. (2010), Making the Numbers? 'Short Termism' \& the Puzzle of Only Occasional Disaster, NBER Working Paper No. 1637, NBER publications. https://doi.org/10.3386/w16367

Repenning, N.P. and Sterman, J.D. (2001), "Nobody ever gets credit for fixing problems that never happened: Creating and sustaining process improvement", California Management Review, Vol. 43 No. 4, pp. 64-88. https://doi.org/10.2307/41166101 
Repenning, N.P. and Sterman, J.D. (2002), "Capability Traps and Self-Confirming Attribution Errors in the Dynamics of Process Improvement", Administrative Science Quarterly, Vol. 47 No. 2, pp. 265-295. https://doi.org/10.2307/3094806

Rodrigues, V.P., Morioka, S.N., Pigosso, D.C.A., Carvalho, M.M. de and McAloone, T.C. (2016a), "Exploring the dynamic and complex integration of sustainability performance measurement into product development", Proceedings of the DESIGN 2016 / $14^{\text {th }}$ International Design Conference, Dubrovnik, Croatia, May 16-19, 2016, pp. 433-442.

Rodrigues, V.P., Pigosso, D.C.A. and McAloone, T.C. (2016b), "Process-oriented performance indicators for measuring ecodesign management practices", Proceedings of the DESIGN $2016 / 14^{\text {th }}$ International Design Conference, Dubrovnik, Croatia, May 16-19, 2016, pp. 443-452.

Rodrigues, V.P., Pigosso, D.C.A. and McAloone, T.C. (2017a), "Measuring the implementation of ecodesign management practices: a review and consolidation of process-oriented performance indicators", Journal of Cleaner Production, Vol. 156, pp. 293-309. https://doi.org/10.1016/j.jclepro.2017.04.049

Rodrigues, V.P., Pigosso, D.C.A. and McAloone, T.C. (2017b), "Building a business case for ecodesign implementation: a System Dynamics approach", Proceedings of the 21st International Conference on Engineering Design (ICED '17), Vol. 1: Resource Sensitive Design, Design Research Applications and Case Studies, Vancouver, Canada, August 21-25, 2017, pp. 179-188.

Starks, H. and Trinidad, S.B. (2007), "Choose Your Method: A Comparison of Phenomenology, Discourse Analysis, and Grounded Theory", Qualitative Health Research, Vol. 17 No. 10, pp. 1372-1380. https://doi.org/10.1177/1049732307307031

Sterman, J.D. (2000), Business Dynamics: Systems Thinking and Modeling for a Complex World, Irwin/McGrawHill, Boston, MA.

Sterman, J.D. (2001), "System dynamics modeling: Tools for learning in a complex world", California Management Review, Vol. 43 No. 4, p. 8-25. https://doi.org/10.2307/41166098

Tatikonda, M.V. (2008), "Product Development Performance Measurement", In: Loch, C.H. and Kavadias, S. (Eds.) The Handbook of New Product Development Management, Elsevier Ltd., Oxford, UK, pp. 199-217.

Teece, D.J. (2007), "Explicating dynamic capabilities: the nature and microfoundations of (sustainable) enterprise performance", Strategic Management Journal, Vol. 28 No. 13, pp. 1319-1350. https://doi.org/10.1002/smj.640

Whelan, T. and Fink, C. (2016), The comprehensive business case for sustainability. [online] Harvard Business Review. Available at: https://hbr.org/2016/10/the-comprehensive-business-case-for-sustainability

Winter, S.G. (2000), "The Satisficing Principle in Capability Learning”, Strategic Management Journal, Vol. 21 No. 10-11, pp. 981-996. https://doi.org/10.1002/1097-0266(200010/11)21:10/11<981::AIDSMJ125>3.0.CO;2-4

Winter, S.G. (2003), "Understanding dynamic capabilities", Strategic Management Journal, Vol. 24 No. 10, pp. 991-995. https://doi.org/10.1002/smj.318

Vinicius Picanco Rodrigues, PhD Researcher

Technical University of Denmark, Department of Mechanical Engineering

Produktionstorvet - Building 426, 2800 Kgs. Lyngby, Denmark

Email: vipiro@dtu.dk 